\title{
Weathering of soils originated from diabase in the Paraná Basin, São Paulo State, Brazil ${ }^{1}$
}

\author{
Intemperismo de solos originários de basalto na bacia do Paraná, São Paulo, Brasil
}

\author{
Clécia Cristina Barbosa Guimarães ${ }^{2}$, José Alexandre Melo Demattề ${ }^{2 *}$, Antônio Carlos de Azevedo ${ }^{2}$, Rafael \\ Cipriano da Silva², Diego Fernando Urbina Salazar ${ }^{2}$
}

\begin{abstract}
Weathering of the parent material is the initial process that plays an essential role in soil fertility. The study of this process has become crucial to better understand soil dynamics. Most studies on weathering are based on indexes that calculate the feldspar dissolution rate (for example, CIA, CIW, and PIA) which not always reflect the complexity in the soil profile. Other methodologies have been designed to improve these approaches, such as geochemical balance, difference of elemental contents (DE), and the $\mathrm{W}$ index. This work aim to assess the efficiency of these methods to identify variations in recent soil profiles developed from diabase as compared to the CIA, CIW, and PIA indexes. Data on the main oxides were used to calculate the geochemical balance, DE, CIA, CIW, PIA, and W indexes to analyze weathering intensity in two profiles originated from diabase in the São Paulo State, Brazil. The Ki and $\mathrm{Kr}$ indexes and $\mathrm{Fe}_{\mathrm{o}} / \mathrm{Fe}_{\mathrm{d}}$ ratio were also factored and we analyzed the mineralogy of soil horizons and the source rock. The $\mathrm{W}$ index and DE presented greater weathering variation than the CIA, CIW, and PIA in both profiles. The geochemical balance, mineralogy, and the $\mathrm{Ki}, \mathrm{Kr}$ and $\mathrm{Fe}_{\mathrm{o}} / \mathrm{Fe}_{\mathrm{d}}$ ratios explained the variations between the horizons. The $\mathrm{DE}$ and geochemical balance together generated new information for the analysis of the weathering process than the isolated indexes.
\end{abstract}

Key words: Mafic rocks. Geochemical balance. Weathering indexes. Element difference.

RESUMO - O intemperismo do material de origem é o processo inicial que garantirá ao solo maior ou menor fertilidade, tornando o estudo desse processo fundamental para entender a dinâmica do solo. Grande parte dos estudos de intemperismo é baseada em índices que calculam a taxa de dissolução dos feldspatos (CIA, CIW e PIA, por exemplo) muitas vezes não refletindo a complexidade do intemperismo ocorrendo no perfil de solo. Outras metodologias- como balanço geoquímico, diferença elementar (DE) e índice W- têm sido desenhadas para melhorar esses estudos. Avaliar se essas metodologias serão mais eficientes que os índices CIA, CIW e PIA para apontar as variações intempéricas em perfis recentes desenvolvidos de basalto é o objetivo desse trabalho. Foram utilizados dados de óxidos principais para calcular o balanço geoquímico, DE, CIA, CIW, PIA e W e analisar a intensidade do intemperismo em dois perfis originados de basalto no Estado de São Paulo. Foram fatorados também os índices Ki e $\mathrm{Kr}$ e a relação $\mathrm{Fe}_{\mathrm{o}} / \mathrm{Fe}_{\mathrm{d}}$ e analisada a mineralogia dos horizontes dos solos e da rocha de origem O índice W e a DE mostraram maior variação intempérica que CIA, CIW e PIA. O balanço geoquímico, a mineralogia e as razões $\mathrm{Ki}$ e $\mathrm{Kr}, \mathrm{Fe}_{\mathrm{o}} / \mathrm{Fe}_{\mathrm{d}}$ foram eficientes em explicar as variações que ocorreram entre os horizontes. A junção da DE com o balanço geoquímico trouxe novas informações para a análise do intemperismo que a observação isolada de CIA, CIW e PIA.

Palavras-chave: Rochas máficas. Balanço geoquímico. Índices de intemperismo. Diferença elementar.

\footnotetext{
DOI: $10.5935 / 1806-6690.20210018$
}

Editor-in-Article: Prof. Tiago Osório Ferreira - toferreira@usp.br

*Author for correspondence

Received for publication on 04/04/2019; approved on 06/05/2021

${ }^{1}$ Parte de tese, Escola Superior de Agricultura Luiz de Queiroz, Universidade de São Paulo

${ }^{2}$ Departamento de Solos, Escola Superior de Agricultura Luiz de Queiroz (ESALQ/USP), Piracicaba- SP. Brasil, clecia@alumni.usp.br (ORCID ID 00000003-2183-9721), jamdemat@usp.br (ORCID ID 0000-0001-5328-0323), aazevedo@usp.br (ORCID ID 0000-0002-1681-3212), ciprorafael@yahoo.com.br (ORCID ID 0000-0002-4392-0275), diego.urbina.salazar@gmail.com (ORCID ID 0000-0002-4327-906X), lucas.rabelo.campos@usp.br (ORCID ID 0000-0003-4799-5036) 


\section{INTRODUCTION}

The Paraná Basin covers an extensive area of the state of São Paulo, Brazil, and the weathering process leads rocks in this basin to form soils of great agricultural importance, accounting for $95 \%$ of sugarcane crop expansion in the central-southern region of Brazil (RUDORFF et al., 2010). This basin is sedimentary where, however, magmatic spills occurred in the Cretaceous period, originating the Serra Geral Formation which consist of extrusive basic rocks, such as basalt (PINHEIRO; QUEIROZ NETO, 2014).

Basalt is particularly sensitive to chemical erosion in a humid tropical climate (BERNER; BERNER, 2012) since high temperatures and humidity favor the weathering process. Furthermore, the low quartz amount in basalt reduces its resistance to chemical weathering. The study of the weathering process of these rocks and soils helps qualification and quantification of chemical elements and soil attributes, which are important for agricultural management.

Geochemical indexes have been used to estimate the weathering degree by monitoring the decomposition of an unstable mineral, a feldspar in most cases, and only $\mathrm{Al}, \mathrm{Ca}, \mathrm{Na}$, and $\mathrm{K}$ are factored (FEDO; NESBITT; YOUNG, 1995; GARZANTI; RESENTINI, 2016; HARNOIS, 1988; LE BLOND et al., 2015; NESBITT; YOUNG, 1989). Ohta and Arai (2007) developed a specific index for igneous rocks $(\mathrm{W})$ that considers all geochemical variability of weathered rocks using element concentrations of the main oxides in the soil. Le Blond et al. (2015) used this index, along with the CIA and CIW indexes, to assess the weathering process of basaltic soils and concluded that only the $\mathrm{W}$ index provided information on the composition of the original rock from which the soil profiles. Oriolo et al. (2019) also used the $\mathrm{W}$ index to characterize igneous rocks used as pigments in cave arts, regarding the composition and weathering degree.

The weathering analysis of a soil profile from rock to the surface should show the relative accumulation of less mobile elements and loss of mobile ones (NOVAES FILHO et al., 2012). These modifications in the elements can be evaluated by geochemical balance (BIDDLE; CHITTLEBOROUGH; FITZPATRICK, 1998) and difference of elemental contents (DE) (WEINDORF et al., 2012). The geochemical balance method relates the chemical composition, density, and volume change of the soil horizons with the rock and allows estimating gains and losses of elements in each horizon (BIDDLE; CHITTLEBOROUGH; FITZPATRICK, 1998), while the difference of elements method is used to differentiate soil horizons or layers (WEINDORF et al., 2012). These techniques together can provide information compatible with the weathering analysis of a soil profile, offering information more detailed on the horizon changes than the weathering indexes that analyze weathering by feldspar dissolution.

Therefore, data from the main soil oxides were used to calculate the $\mathrm{W}$ index, geochemical balance, and DE to evaluate two profiles originated from basalt and compare them with the CIA, CIW, and PIA indexes. We also used data from mineralogy, crystallinity of iron oxides $\left(\mathrm{Fe}_{\mathrm{o}}\right.$ and $\mathrm{Fe}_{\mathrm{d})}$ and $\mathrm{Ki}$ and $\mathrm{Kr}$ indexes. The use of these techniques together can offer a more accurate and in-depth analysis of the weathering process of soils originated from basalt.

\section{MATERIAL AND METHODS}

The study site is located in the municipality of Piracicaba, São Paulo State, Brazil, and is contained in the Peripheral Depression of the Paraná Basin, filled with sedimentary packages and intrusions of volcanic rocks. The profiles collected belong to the Serra Geral Formation and originate from basalt. One profile was collected a control slope near the escarpment of the Western Paulista Plateau (P1) and the other from a tabular body ("sill") that was housed horizontally between the rocks of the Corumbataí Formation (CF) (P2) (Figure 1a). The climate is tropical humid of the "Cwa" type according to Köppen classification (ALVARES et al., 2013), with rainy summers and dry winters and average annual precipitation of $1259 \mathrm{~mm}$. The mean annual temperature is $25^{\circ} \mathrm{C}$.

We cleaned a lateral section of $0.50 \mathrm{~m}$ from the soil surface to the rocky material and the morphological description was conducted according to Santos et al. (2015). We collected deformed and undeformed soil and rock samples in duplicate. The rock samples had already shown signs of changes and were collected from loose material close to the soil profile, due to the difficulty to collect samples below the profile. The fine earth samples were oven-dried at $45^{\circ} \mathrm{C}$ (TFSE), loosened, and sieved through a 2-mm mesh and then the physical, chemical, and mineralogical characterization was carried out. The densimeter method was used to determine the clay fraction, sand was determined by sieving, and silt was calculated by the difference between total sand and clay (TEIXEIRA et al., 2017).

The organic matter $(\mathrm{OM})$ content was determined from its wet oxidation with potassium dichromate in an acidic medium followed by titration with ammoniacal ferrous sulfate. The $\mathrm{pH}$ was determined in water and in $\mathrm{KCl}$. The available phosphorus (P), exchangeable potassium $(\mathrm{K})$ and sodium $(\mathrm{Na})$ were extracted by an acidic Mehlich-1 solution. The $\mathrm{P}$ content was determined by photocolorimetry, while $\mathrm{K}$ and $\mathrm{Na}$ were determined by flame photometry. The exchangeable calcium $(\mathrm{Ca})$, magnesium $(\mathrm{Mg})$ and aluminum $(\mathrm{Al})$ were extracted 
Figure 1 - Location and geology of profiles 1 and 2. Study site showing the geology of the profiles collected (a); Relief and visual identification, respectively, of profile 1 (Eutric Rhodic Nitisol (Ochric)) (b, c); Relief and visual identification, respectively, of profile 2 (Leptic Someric Kastanozem (Arenic)) (d, e)

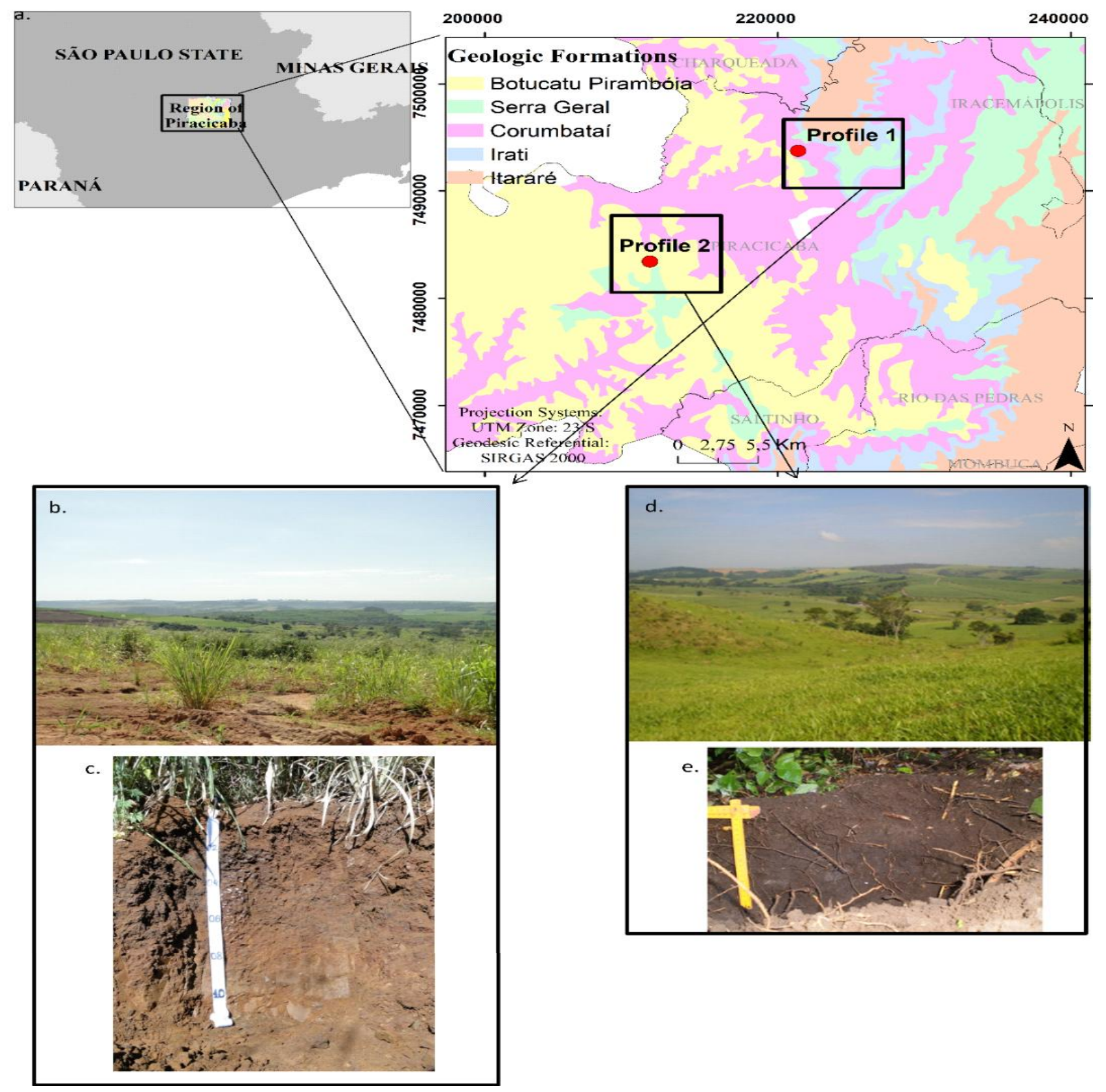

by $\mathrm{KCl}$ solution $\left(1 \mathrm{~mol} \cdot \mathrm{L}^{-1}\right)$. The $\mathrm{Ca}$ and $\mathrm{Mg}$ contents were determined by atomic absorption spectrophotometry, while $\mathrm{Al}$ was determined by titration with a dilute solution of $\mathrm{NaOH}$, using bromothymol blue as indicator. The potential acidity was determined with a buffered calcium acetate solution at $\mathrm{pH} 7$ followed by titration with $\mathrm{NaOH}$ in the presence of phenolphthalein as an indicator. The data collected were used to calculate $\Delta \mathrm{pH}\left(\mathrm{pH}_{\mathrm{KCl}}-\mathrm{pH}_{\mathrm{H} 2 \mathrm{O}}\right)$, sum of bases (SB), cation exchange capacity (CEC), base saturation (V\%), and aluminum saturation (m\%) (TEIXEIRA et al., 2017). These values were used for soil classification, accompanied by morphological descriptions of the profiles carried out in the field. The profiles were classified according to the World Reference Base for Soil Resources (WRB, 2015).

The TFSE samples were melted at $1000{ }^{\circ} \mathrm{C}$ with lithium metaborate $\left(\mathrm{LiBO}_{2}\right)$, with subsequent dissolution in a solution containing nitric acid (4\%) and hydrochloric acid $(2 \%)$ to determine the elements expressed in 
constituent oxides: $\mathrm{SiO}_{2}, \mathrm{Al}_{2} \mathrm{O}_{3}, \mathrm{Fe}_{2} \mathrm{O}_{3}, \mathrm{CaO}, \mathrm{MgO}, \mathrm{Na}_{2} \mathrm{O}$, $\mathrm{K}_{2} \mathrm{O}, \mathrm{TiO}_{2}$ and $\mathrm{MnO}$. The reading of the contents was performed by inductively coupled plasma atomic emission spectrometry (ICP-AES) and the percentage of each oxide was calculated and corrected for mass loss on ignition. We used samples SY-4 and GBM303-4 as reference standards. Mass loss (water and volatile elements of samples) (LOI= loss on ignition) was determined after heating the material to about $1,000{ }^{\circ} \mathrm{C}$ (LE BLOND et al., 2008).

The mathematical indexes of weathering intensity were calculated from element data, namely: Chemical Index of Alteration (CIA) $=100 \cdot\left(\frac{\mathrm{Al}_{2} \mathrm{O}_{3}}{\mathrm{Al}_{2} \mathrm{O}_{3}+\mathrm{CsO}_{\mathrm{O}} \mathrm{Na}_{2} \mathrm{O}+\mathrm{K}_{2} \mathrm{O}}\right) \mathrm{NESBITT}$; YOUNG, 1982), Chemical Index of Weathering (CIW) $=$ 100. $\left(\frac{\mathrm{Al}_{2} \mathrm{O}_{8}}{\mathrm{Al}_{2} \mathrm{O}_{\mathrm{s}}+\mathrm{CaO}_{\mathrm{O}}+\mathrm{Na}_{2} \mathrm{O}}\right)$ (HARNOIS, 1988), Plagioclase Index of Alteration (PIA) $=100 .\left(\frac{{ }_{\left(A l_{2} O S-K_{2} O\right)}}{\left(A l_{2} O S+C a O+N a_{2} O-K_{2} O\right.}\right)($ FEDO; NESBITT; YOUNG, 1995), and the statistical empirical index of chemical weathering specific for igneous rocks (W) (OHTA; ARAI, 2007).

The geochemical balance was calculated based on rock composition according to Biddle, Chittleborough and Fitzpatrick (1998), using the density of soil samples measured by the volumetric ring method and by the paraffin clod method for rocks (TEIXEIRA et al., 2017). Titanium (Ti) was considered the index for data normalization.

The difference of elemental contents $(\mathrm{DE})_{\mathrm{n}}=$ $\left(\sqrt{ } \sum_{\mathrm{i}-1}^{\mathrm{F}}\left(\mathrm{L}_{\mathrm{i}(\mathrm{n}-1)}-\mathrm{L}_{\mathrm{in}}\right)^{2}\right.$ was calculated between soil horizons and rock layers. DE was the difference of the element content of a soil horizon or rock layer $n$ in relation to the horizon or layer above. F was the number of principal component obtained in PCA. L(n-1) and L(n) were the loadings of the soil horizon or rock layer $\mathrm{n}$ and the horizon or layer $n-1$ above the principal component $\mathrm{i}$, respectively (WEINDORF et al., 2012).

The clay fraction samples were solubilized with $\mathrm{H}_{2} \mathrm{SO}_{4} 1: 1$ to calculate the molecular ratios $\mathrm{Ki}=\frac{\%_{\left(\% \mathrm{SiO}_{2} * 1.70\right.}}{\%_{\mathrm{Al}} \mathrm{O}_{2} \mathrm{Os}}$ and

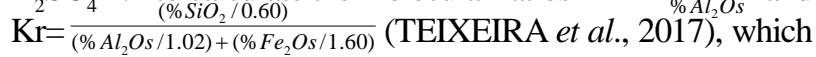
allowed evaluating the soil weathering degrees.

Free crystalline Fe compounds in soil samples $\left(\mathrm{Fe}_{\mathrm{d}}\right)$ extracted by citrate-thionite-bicarbonate solution (MEHRA; JACKSON, 1960) were determined by atomic absorption spectrometry, while little crystalline iron compounds $\left(\mathrm{Fe}_{\mathrm{o}}\right)$ were extracted with ammonium acid oxalate solution (SCHWERTMANN, 1964). The relationship between these two Fe forms was used to determine the crystallinity degree of $\mathrm{Fe}$ oxides and were useful to estimate the weathering degree (ZHENG et al., 2016).

The exploratory mineralogical analysis was performed on TFSE samples of soil and rock powder by X-ray diffraction (JACKSON, 1969). The X-ray diffractograms were obtained in the Miniflex II Desktop $\mathrm{X}$-Ray Diffractometer Rigaku, operating in the continuous acquisition mode, voltage $30 \mathrm{Kv}$, current $20 \mathrm{~mA}$, and $\mathrm{CuK} \alpha$ radiation, at the interval 3 to $40^{\circ} 2 \theta, 5$ seconds/ step and $0.02^{\circ} 2 \theta$ step. Mineral identification was based on interplanar spacing (d) (BROWN; BRINDLEY, 1980) and on the behavior of diffraction peaks observed in the Match! 3.2.1. (PUTZ, 2016).

\section{RESULTS AND DISCUSSION}

Profile 1 (P1) was collected in the lower third of a slope with approximately $16 \%$ slope, under anthropogenic forest and classified as a Eutric Rhodic Nitisol (Ochric) (WRB, 2015) (Figures $1 \mathrm{~b}$ and 1c). The profile was 1.20 $\mathrm{m}$ deep and had a sequence of A-Bt-BC-CB-Cr horizons. Horizon A showed a moderate degree of development of a lumpy structure with medium size. Horizon Bt was well developed with large angular blocks and abundant and strong waxiness. Horizon BC showed moderate and common waxiness. Horizons $\mathrm{CB}$ and $\mathrm{Cr}$ had an appearance of reddish-yellowish mottles (7.5YR 7/6) and $\mathrm{Cr}$ also showed ferromanganese nodules of effervescence with light and strong hydrogen peroxide. These nodules are formed from Mn oxide minerals with low crystallinity and low concentration, which hinders their characterization, and are mostly formed by chemical precipitation from the solution and by crystallization of disorganized colloids (CARVALHO FILHO et al., 2011).

$\mathrm{P} 1$ is located on the perimeter of a basalt sill intruded in the Corumbataí Formation (CF) (siltites and shales), where there is basalt extraction and comminution activity. P1 has certain peculiarities, such as the smaller clay amount in horizon $\mathrm{Bt}$ (despite the presence of waxiness) and higher exchangeable $\mathrm{K}$ content in relation to $\mathrm{Ca}\left(1.4 \mathrm{~K} \mathrm{cmol} \cdot \mathrm{kg}^{-1}\right.$ and $1.2 \mathrm{cmol}_{\mathrm{c}} \cdot \mathrm{kg}^{-1}$ of $\mathrm{Ca}$ in horizon $\mathrm{A}$, and $1.5 \mathrm{~K} \mathrm{cmol} \cdot \mathrm{kg}^{-1}$ and $1.3 \mathrm{cmol}_{\mathrm{c}} \cdot \mathrm{kg}^{-1}$ of $\mathrm{Ca}$ in horizon Bt, Table 1). Several local factors and processes must contribute to these peculiarities. The presence of more fine particles in horizon A may be due to atmospheric deposition of particles generated by the diabase comminution activity in nearby mining (approximately $350 \mathrm{~m}$ from the profile). These particles must have particle size too fine to be transported by air.

Sill diabase has a particularly rich chemical composition in $\mathrm{K}\left(1.8 \% \mathrm{~K}_{2} \mathrm{O}\right.$, Table 1$)$ at the expense of a lower $\mathrm{Ca}$ concentration than normally observed (7.1\% CaO, Table 1). Gill (2010) lists the composition of representative basalts in tectonic environments worldwide and only two examples have $\mathrm{K}_{2} \mathrm{O}$ greater than $1 \%$ of the eight examples. Furthermore, the contribution of materials from the surrounding $\mathrm{CF}$ cannot be disregarded and could result in a higher silt content (predominant in rocks of this formation) and 2:1 potassium-rich phyllosilicates (present in the $\mathrm{CF}$ in 
Table 1 - Physical and chemical attributes of the Eutric Rhodic Nitisol (Ochric) (Profile 1) and Leptic Someric Kastanozem (Arenic) (Profile 2) Profile 1 Profile 2

\begin{tabular}{|c|c|c|c|c|c|c|c|c|c|c|}
\hline & & A & $\mathrm{Bt}$ & $\mathrm{BC}$ & $\mathrm{CB}$ & $\mathrm{Cr}$ & $\mathrm{R}$ & A & $\mathrm{Cr}$ & $\mathrm{R}$ \\
\hline Depth & $\mathrm{m}$ & 0.2 & 0.4 & 0.6 & 1.1 & 1.2 & - & 0.2 & 0.3 & - \\
\hline & & \multicolumn{9}{|c|}{ Particle size } \\
\hline Sand & \multirow{3}{*}{$\%$} & 23.3 & 26.0 & 22.2 & 19.8 & 29.4 & - & 66.2 & 68.4 & - \\
\hline Silt & & 13.6 & 17.6 & 9.1 & 11.1 & 25.6 & - & 19.9 & 13.3 & - \\
\hline \multirow[t]{2}{*}{ Clay } & & 63.1 & 56.3 & 68.7 & 69.0 & 45.0 & - & 14.0 & 18.3 & - \\
\hline & & \multicolumn{9}{|c|}{ Chemical analysis } \\
\hline $\mathrm{pH}_{\mathrm{H} 2 \mathrm{O}}$ & \multirow{12}{*}{$\mathrm{cmol}_{\mathrm{c}} \cdot \mathrm{Kg}^{-1}$} & 7.0 & 7.1 & 7.0 & 6.6 & 6.3 & - & 6.0 & 6.1 & - \\
\hline $\mathrm{pH}_{\mathrm{KCl}}$ & & 5.9 & 5.9 & 6.0 & 5.7 & 5.1 & - & 5.2 & 4.8 & - \\
\hline$\Delta \mathrm{pH}^{1}$ & & -1.1 & -1.2 & -1.0 & -0.9 & -1.2 & - & -0.8 & -1.3 & - \\
\hline $\mathrm{Al}^{3+}$ & & 0.0 & 0.0 & 0.0 & 0.0 & 0.0 & - & 0.0 & 0.2 & - \\
\hline $\mathrm{Na}^{+}$ & & 0.0 & 0.0 & 0.0 & 0.0 & 0.1 & - & 0.0 & 0.0 & - \\
\hline $\mathrm{K}^{+}$ & & 1,4 & 1,5 & 1,4 & 0,9 & 0,4 & - & 1,1 & 0,9 & - \\
\hline $\mathrm{H}+\mathrm{Al}$ & & 1.2 & 1.8 & 1.1 & 1.2 & 1.6 & - & 2.1 & 2.7 & - \\
\hline $\mathrm{Ca}^{+2}$ & & 1.2 & 1.3 & 1.4 & 1.9 & 2.4 & - & 15.9 & 13.2 & - \\
\hline $\mathrm{Mg}^{2+}$ & & 0.4 & 0.4 & 0.4 & 0.6 & 0.8 & - & 4.5 & 4.5 & - \\
\hline $\mathrm{SB}^{2}$ & & 3.1 & 3.3 & 3.3 & 3.5 & 3.6 & - & 21.5 & 18.6 & - \\
\hline $\mathrm{CTC}_{\mathrm{pH} 7}{ }^{3}$ & & 4.4 & 5.1 & 4.4 & 4.7 & 5.3 & - & 23.6 & 21.3 & - \\
\hline Ativ. Arg. ${ }^{4}$ & & 7.0 & 9.1 & 6.4 & 6.8 & 11.7 & - & - & - & - \\
\hline $\mathrm{V}^{5}$ & $\%$ & 71.3 & 65.0 & 74.9 & 74.4 & 69.0 & - & 91.1 & 87.3 & - \\
\hline \multirow[t]{2}{*}{$\mathrm{OM}^{6}$} & g. $\mathrm{Kg}^{-1}$ & 18.6 & 21.1 & 15.8 & 9.3 & 5.7 & - & 50 & 32 & - \\
\hline & & \multicolumn{9}{|c|}{ Total chemistry analysis* } \\
\hline $\mathrm{SiO}_{2}$ & & 51.0 & 51.1 & 52.7 & 47.8 & 49.5 & 53.3 & 58.5 & 55.2 & 53.0 \\
\hline $\mathrm{Al}_{2} \mathrm{O}_{3}$ & & 19.1 & 15.9 & 20.0 & 22.1 & 20.0 & 12.4 & 13.5 & 15.6 & 15.9 \\
\hline $\mathrm{Fe}_{2} \mathrm{O}_{3}$ & & 22.0 & 23.7 & 20.1 & 21.7 & 21.1 & 14.7 & 14.8 & 14.5 & 12.7 \\
\hline $\mathrm{CaO}$ & & 0.3 & 0.5 & 0.5 & 0.6 & 0.7 & 7.1 & 2.6 & 3.5 & 6.1 \\
\hline $\mathrm{MgO}$ & $\%$ & 0.5 & 0.5 & 0.5 & 0.9 & 1.4 & 3.5 & 1.3 & 1.8 & 2.9 \\
\hline $\mathrm{Na}_{2} \mathrm{O}$ & & 0.1 & 0.2 & 0.1 & 0.6 & 0.6 & 2.7 & 1.1 & 1.5 & 2.7 \\
\hline $\mathrm{K}_{2} \mathrm{O}$ & & 0.4 & 0.6 & 0.4 & 1.1 & 1.4 & 1.8 & 2.5 & 2.7 & 2.4 \\
\hline $\mathrm{TiO}_{2}$ & & 5.9 & 6.7 & 5.1 & 4.5 & 4.6 & 3.4 & 4.5 & 3.9 & 2.8 \\
\hline $\mathrm{MnO}$ & & 0.2 & 0.3 & 0.2 & 0.2 & 0.3 & 0.2 & 0.4 & 0.3 & 0.2 \\
\hline \multirow[t]{2}{*}{ LOI } & & 13.6 & 13.3 & 14.5 & 17.4 & 13.8 & 3.0 & 12.6 & 10.9 & 5.7 \\
\hline & & \multicolumn{9}{|c|}{ Clay fraction analysis (sulfuric attack) } \\
\hline $\mathrm{Al} 2 \mathrm{O}_{3}$ & \multirow{4}{*}{$\%$} & 16.0 & 12,8 & 16,3 & 17.2 & 14.0 & - & 6.9 & 7.9 & - \\
\hline $\mathrm{Fe}_{2} \mathrm{O}_{3}$ & & 17.7 & 17,2 & 15.2 & 18.8 & 15.8 & - & 16.1 & 16.0 & - \\
\hline $\mathrm{SiO}_{2}$ & & 18,9 & 17,1 & 20.2 & 21.0 & 20.4 & - & 12.7 & 14.1 & - \\
\hline \multirow[t]{2}{*}{$\mathrm{TiO}^{2}$} & & 3,0 & 3,0 & 2.6 & 2.1 & 1.7 & - & 2.3 & 2.2 & - \\
\hline & & \multicolumn{9}{|c|}{ Iron selective dissolution } \\
\hline $\mathrm{Fe}_{\mathrm{d}}{ }^{7}$ & $\mathrm{mg} \cdot \mathrm{Kg}^{-1}$ & 819.0 & 797.8 & 788.6 & 678.7 & 584.4 & 93.3 & 337.5 & 276.5 & 124.1 \\
\hline $\mathrm{Fe}_{0}^{8}$ & & 83.0 & 130.2 & 94.6 & 125.1 & 106.7 & 333.6 & 103.1 & 120.1 & 57.3 \\
\hline
\end{tabular}

1 - balance of electrical charges ( $\mathrm{pHKCl}$ - $\left.\mathrm{pHH}_{2} \mathrm{O}\right) ; 2$ - sum of bases; 3 - cation exchange capacity at $\mathrm{pH} 7 ; 4$ - clay activity; 5 - percentage of cation saturation; 6 - concentration of organic matter; 7 - concentration of iron extracted with dithionite (crystalline iron); 8 - concentration of iron extracted with oxalate (less crystalline iron); * oxide concentration corrected by LOI 
variable amounts). Nearby profiles excavated in $\mathrm{CF}$ studied by Guimarães et al. (2021) (P2 and P3) resulted in $2.3 \%$ and $4.9 \%$ of $\mathrm{K}_{2} \mathrm{O}$ and only $0.1 \%$ and $0.4 \%$ of $\mathrm{CaO}$. These non-exclusive hypotheses can explain the large concentration of exchangeable $\mathrm{K}$, even higher than that of $\mathrm{Ca}$ in this profile (Table 1 ).

Profile 2 (P2) was collected in native forest in the upper third of a hillside at a slope of $42 \%$ and classified in WRB (2015) as a Leptic Someric Kastanozem (Arenic) (Figures 1d and 1e). The profile is about $0.35 \mathrm{~m}$ deep and presented a sequence of dark colored A-Cr horizons (10 YR 2/1), due to the high OM concentration (Table 1) and the material of mafic origin with a degree of weak structuring of small subangular block type.

P1 showed greater differentiation of horizons with higher clay content throughout the profile and formation of a nitic $\mathrm{B}$ horizon (Bt), diagnosed by the development of pedic structure, clay contents, and presence of waxiness (Table 1). P2 has sand predominance and abundance of primary minerals with potential for clay formation. The pedogenetic difference between both profiles of the same source material and climatic zone was mainly due to the different positions in the relief. $\mathrm{P} 2$ is located in a region of greater slope and experiences faster losses due to erosion, making the profile shallow with less pedogenetic development (BUOL et al., 2011). On the other hand, P1 is on a smaller slope, favoring pedogenetic development, expressed by the greater differentiation of horizons and greater depth.

The lowest values of clay activity in P1 indicate predominance of 1:1 clay oxides and phyllosilicates, represented mainly by kaolinite in Nitosol and the OM contributes more to the amounts of negative charges (Table 1). The kaolinite reflexes are visible from the deepest horizons in P1 XRD (peaks at $12.6^{\circ} 2 \Theta$ angle) and the peaks of 2:1 phyllosilicates in the region of the $8.8^{\circ} 2 \Theta$ angle disappear in surface horizons (Figure 2a).

In $\mathrm{P} 2$, only the presence of 2:1 phyllosilicate occurs (Figure 3a). The XRD analyses were performed in the TFSE; therefore, it is not possible to affirm where the sand, silt, or clay fractions occur. In the case of sand and silt fractions, this mineral group is represented by primary micas or illites, which are not very abundant or are absent in basalts. However, in the basalts and diabases of the Serra Geral Fm, where these rocks have a tholeiitic character, these minerals occur in small amounts. If phyllosilicates 2:1 occur in the clay fraction, which is more likely, they have pedogenetic origin, such as montmorillonite or vermiculite minerals. The latter hypothesis is supported by the high $\mathrm{Ki}$ and CTC values of this profile (Table 1). In the silt fraction, these minerals become the main candidates for the source of $\mathrm{K}$.

The CIA, CIW, and PIA values for rocks of igneous composition range from 35 to 50 , with mafic rocks occupying the lowest values (BABECHUCK; WIDDOWSON; KAMBER, 2014; LE BLOND et al., 2015). Unlike the findings of these authors, P1 and P2 presented rocks with values around 50 for these indexes (Figures $2 \mathrm{~b}$ and $3 \mathrm{~b}$ ). The source material of both profiles was collected from the soil surface and had already started to weather; therefore, their values were higher.

During chemical weathering, CIA, CIW, and PIA increase due to the loss of mobile elements (BABECHUCK; WIDDOWSON; KAMBER, 2014). In $\mathrm{P} 1$ horizons, the values of these indexes approached 100 at the transition from rock to soil. In P2 horizons, the increase was much less evident, lower than 80 , with low variation along the profile (Figures $2 b$ and $3 b$ ). Values below 80 indicate that the most resistant samples still keep a detectable amount of mobile elements $(\mathrm{Ca}, \mathrm{Na}$, and $\mathrm{K}$ ) that were retained in primary minerals, such as plagioclases, pyroxenes, and clay phyllosilicates identified in P2 XRD (Table 2; Figure 3a). Values above 80 , as in the $\mathrm{P} 1$ horizons, indicate the almost complete removal of the main mobile elements (BABECHUCK; WIDDOWSON; KAMBER, 2014) (Table 2). The location of the lowest slope of P1 favored the permanence of soil particles and greater weathering differentiation.

The CIA, CIW, and PIA values increased towards the soil surface, with greater weathering degree of horizon A in P1 and P2, which is expected because particles on the soil surface are in greater contact with external weathering agents (Figures $2 \mathrm{~b}$ and $3 \mathrm{~b}$ ). These indexes reduced slightly in horizon $\mathrm{Bt}$ in $\mathrm{P} 1$ due to the increase in the reflexes of plagioclases and amphibole in XRD (Figures $2 \mathrm{~b}$ and 2a), reinforcing hypothesis of atmospheric deposition, also reported by Ferreira, Guerra and Azevedo (2021). The small variation of these indexes along the profiles occurred because the calculation was based only on oxides $\mathrm{Al}_{2} \mathrm{O}_{3}$, $\mathrm{K}_{2} \mathrm{O}, \mathrm{CaO}$, and $\mathrm{Na}_{2} \mathrm{O}$ (Figures $2 \mathrm{~b}$ and $3 \mathrm{~b}$ ). According to Babechuck, Widdowson and Kamber (2014), these indexes are not efficient in more advanced weathering stages, because after the extensive loss of bases (considered in CIA, CIW, and PIA indexes), desilication predominates and $\mathrm{SiO}_{2}$ is not considered in the indexes. On the other hand, there is a residual concentration of $\mathrm{Fe}$ and $\mathrm{Al}$ oxides.

The $\mathrm{Ki}$ and $\mathrm{Kr}$ indexes were tested due to the particularities mentioned above (Figures 2c and 3c). However, these indexes changed slightly in both profiles as they relate to pedogenetic processes. Weathering causes the silica loss from the primary minerals; on the other hand, pedogenesis causes the permanence of part of this silica in secondary phyllosilicates of great stability in the profile. In $\mathrm{P} 1, \mathrm{Ki}$ and $\mathrm{Kr}$ values were close to or above 1.5, indicating predominance of phyllosilicates $1: 1, \mathrm{Fe}$ and $\mathrm{Al}$ oxides, and hydroxides in the clay fraction (Figure 2c). High annual precipitation rates favor the formation of these minerals 
Figure 2 -XRD of soil and rock horizons TFSE (a), weathering indexes CIA, CIW and PIA (b), Ki, Kr, Feo/Fed ratios (c) and difference of elemental contents (DE) (d) of the Eutric Rhodic Nitisol (Ochric) (P1); Weathering index specific for mafic rocks (W) of horizons and rock of the Eutric Rhodic Nitisol (Ochric) (P1) and Leptic Someric Kastanozem (Arenic) (P2) (e)

a.
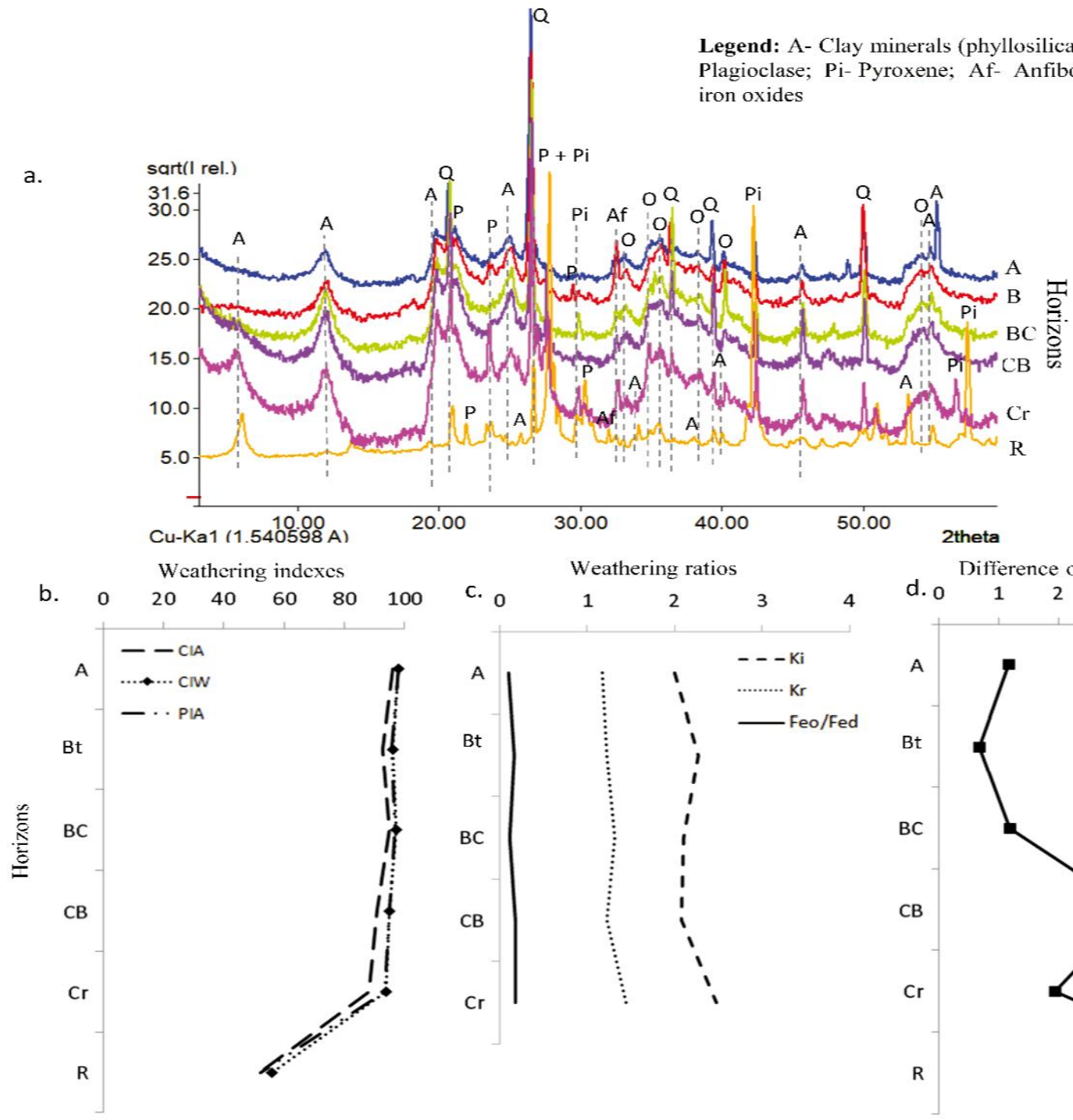

Weathering ratios Plagioclase; Pi- Pyroxene; Af- Anfibole; O- Secondary

eathering indexes

C. 0

1

2

3

4

d. $\begin{array}{ccccc}\text { Difference of elements (DE) } \\ 0 & 1 & 2 & 3 & 4\end{array}$
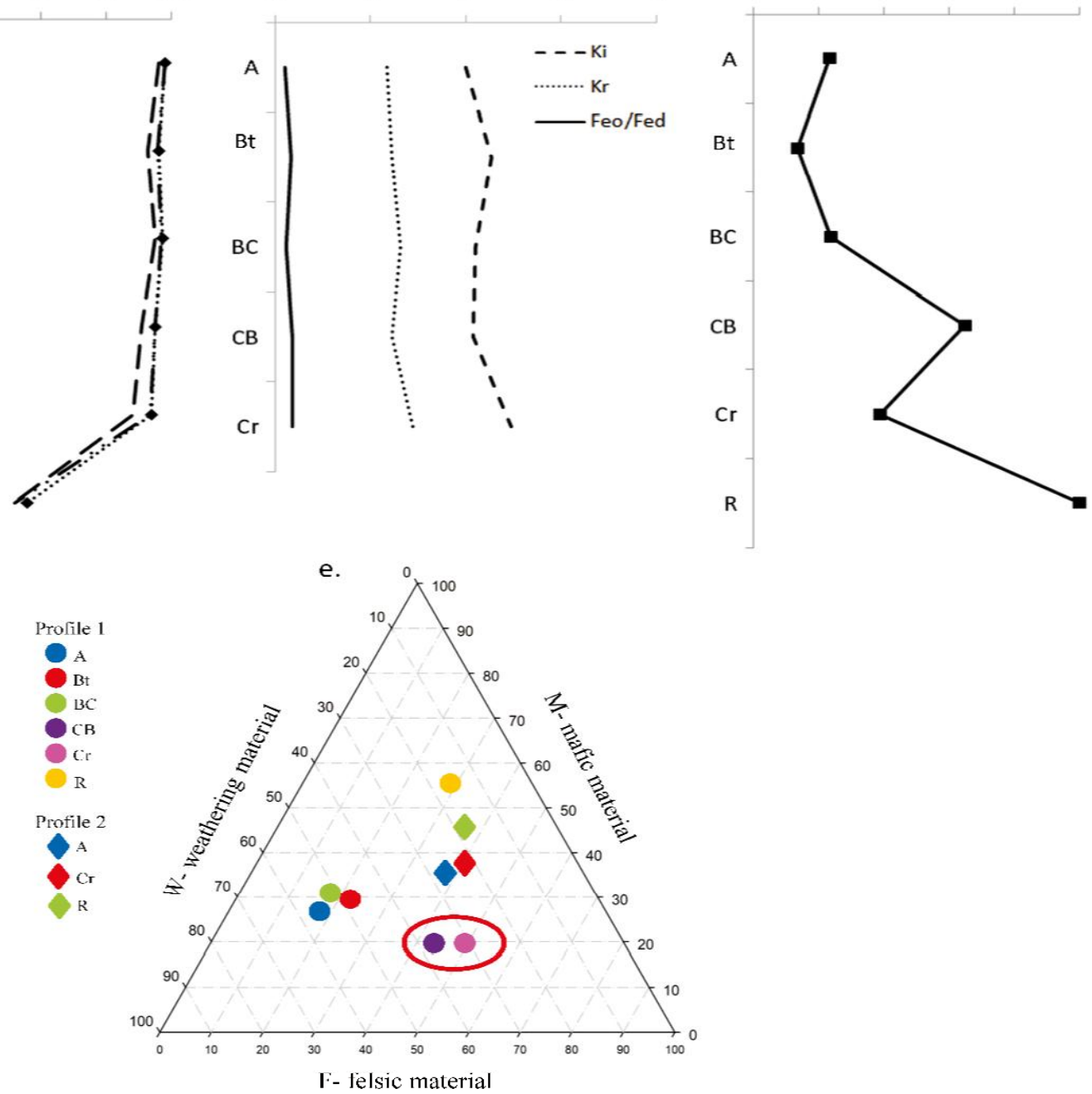
Figure 3 -XRD of soil and rock horizons TFSE (a), weathering indexes CIA, CIW, and PIA (b), Ki, Kr, Feo/Fed ratios (c) and difference of elemental contents (DE) (d) of Leptic Someric Kastanozem (Arenic) (P2)

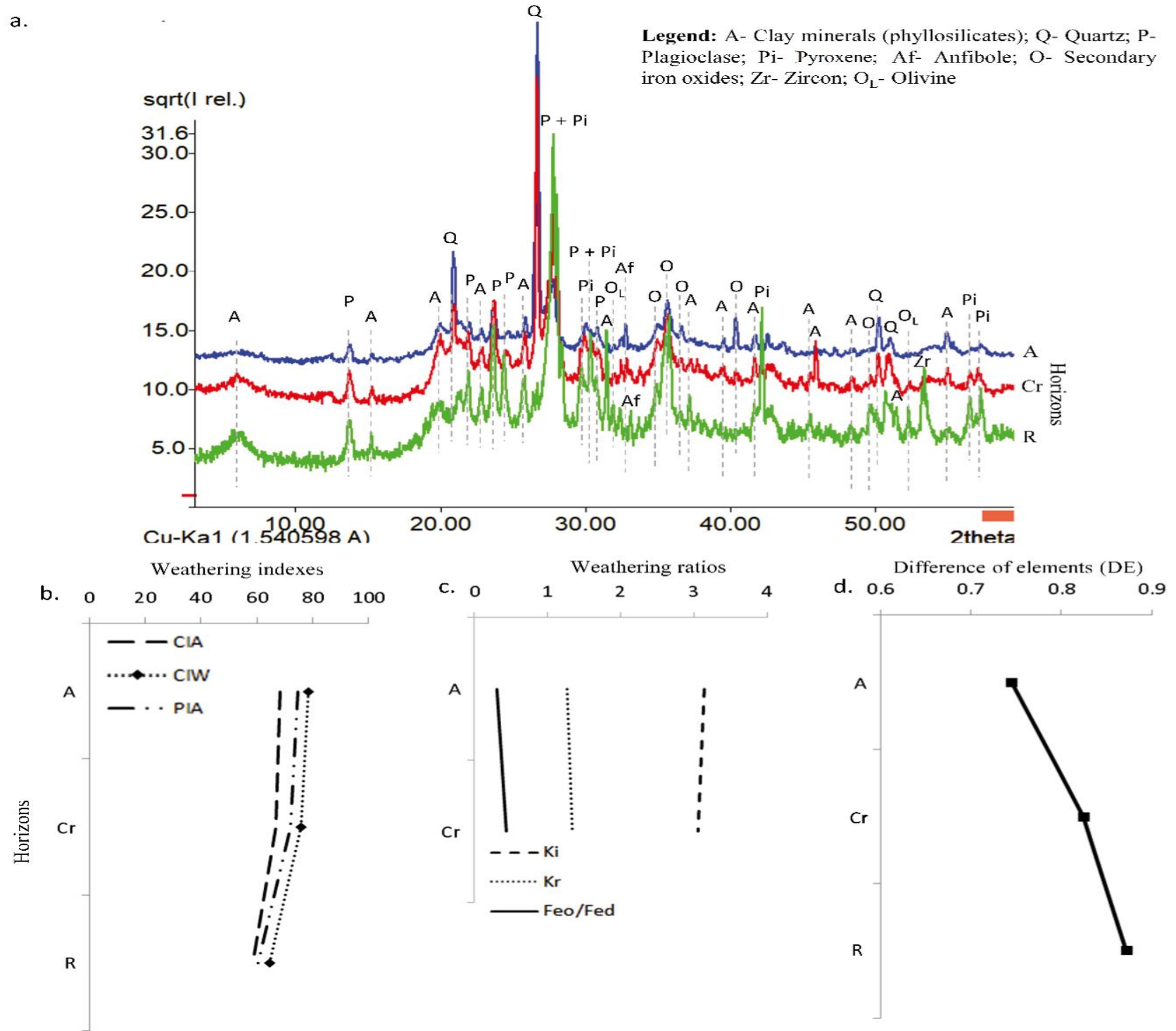

Table 2 - Geochemical balance calculated from the ICP-AES analysis of the Eutric Rhodic Nitisol (Ochric) (P1) and the Leptic Someric Kastanozem (Arenic) (P2)

\begin{tabular}{|c|c|c|c|c|c|c|c|}
\hline & $\mathrm{SiO} 2$ & $\mathrm{Al} 2 \mathrm{O} 3$ & $\mathrm{Fe} 2 \mathrm{O} 3$ & $\mathrm{MgO}$ & $\mathrm{CaO}$ & $\mathrm{K} 2 \mathrm{O}$ & $\mathrm{Na} 2 \mathrm{O}$ \\
\hline \multicolumn{8}{|c|}{$\mathrm{P} 1$} \\
\hline $\mathrm{A}$ & -45.2 & -11.8 & -14.3 & -91.2 & -97.4 & -88.0 & -98.0 \\
\hline $\mathrm{Bt}$ & -51.5 & -35.0 & -18.5 & -92.9 & -96.4 & -83.7 & -96.9 \\
\hline $\mathrm{BC}$ & -34.1 & 7.6 & -8.8 & -89.6 & -95.5 & -84.4 & -96.8 \\
\hline CB & -31.7 & 35.7 & 12.2 & -79.8 & -93.7 & -53.0 & -84.0 \\
\hline $\mathrm{Cr}$ & -31.3 & 19.1 & 6.3 & -69.8 & -92.9 & -42.5 & -82.2 \\
\hline \multicolumn{8}{|c|}{$\mathrm{P} 2$} \\
\hline $\mathrm{A}$ & -30.2 & -46.6 & -26.7 & -71.7 & -73.2 & -34.5 & -73.3 \\
\hline $\mathrm{Cr}$ & -24.9 & -29.4 & -17.9 & -55.6 & -58.6 & -19.3 & -59.9 \\
\hline
\end{tabular}


(LE BLOND et al., 2015). The annual precipitation in the study site is low, with the occurrence of water deficit in several months of the year, slowing down the formation of phyllosilicates 1:1 and originating minerals 2:1 and 1:1, such as kaolinite and smectites. XRD showed several reflections of clay phyllosilicates; however, a clear identification of the presence of kaolinite and smectite was not possible due to the lack of particle size separation and the non-application of chemical methods to distinguish the minerals (Figures $2 \mathrm{a}$ and $3 \mathrm{a}$ ).

$\mathrm{Ki}$ reduced in horizon $\mathrm{A}$ of $\mathrm{P} 1$ due to greater weathering of primary minerals, whose reflections in XRD reduced compared to horizon Bt. Furthermore, the increase in clay mineral reflections in XRD in horizon A indicates the formation of secondary phyllosilicates, such as kaolinite. According to Melfi and Levi (1971), kaolinite is the most abundant pedogenetic phyllosilicate in the final weathering stages of basic rocks, such as basalt, resisting the pedogenetic modification processes.

The high $\mathrm{Ki}$ value in P2 indicates a mineralogical composition strongly influenced by phyllosilicates $2: 1$, which also justifies the higher CEC in the profile (Figure 3c). In P2 specifically, greater reflections of 2:1clay phyllosilicates in horizon A were expected due to the high $\mathrm{Ki}$ value; nevertheless, this did not occur because of the method to obtain XRD.

The increase in secondary Fe oxides in surface horizons of both profiles is expressed by the $\mathrm{Kr}$ reduction and the increase in $\mathrm{Fe}_{\mathrm{d}}$ values (Figures 2c and $3 \mathrm{c}$, and Table 1). In horizons $\mathrm{Bt}$ and $\mathrm{CB}$ in $\mathrm{P} 1$, the increase in the $\mathrm{Fe}_{\mathrm{o}} / \mathrm{Fe}_{\mathrm{d}}$ ratio indicates that low crystalline $\mathrm{Fe}$ oxides are contributing more to the $\mathrm{Kr}$ decrease (Figure 2c). The presence of sharper oxide reflections in XRD of horizon Bt also indicates an increase in crystalline Fe oxides in this horizon (Figure 2a). The values of the $\mathrm{Fe}_{\mathrm{o}} / \mathrm{Fe}_{\mathrm{d}}$ ratio did not vary greatly in $\mathrm{P} 2$, while $\mathrm{Kr}$ was invariable (Figure 3c). Only horizon A presented greater differentiation regarding the presence of crystalline Fe oxides and the horizon XRD showed more intense reflections of these minerals (Figure 3a).

The CIA, CIW, and PIA weathering indexes may not explain the changes during real weathering scenarios, as they do not consider subtle variations, such as mineral or chemical heterogeneity in the rock matrix or the variable behavior of some soil components (LE BLOND et al., 2015). Furthermore, the profiles analyzed in this work were not in advanced weathering stages to allow the $\mathrm{Ki}$ and $\mathrm{Kr}$ indexes to show greater variations and be more suitable for the weathering analysis. Thus, the weathering index W was also tested (OHTA; ARAI, 2007) and the horizon samples of both profiles were plotted in a ternary diagram containing the indexes indicative of felsic $(\mathrm{F})$ and mafic rocks $(\mathrm{M})$, in addition to the variable $\mathrm{W}$ (Figure $2 \mathrm{e}$ ).
Similar to the study of Szilas and Garde (2013), the $\mathrm{W}$ index proved to be a good indicator of the geochemical changes during weathering in P1, showing a better performance to differentiate the horizons than CIA, CIW, PIA, Ki and $\mathrm{Kr}$ (Figure 2e). Horizons $\mathrm{Cr}$ and $\mathrm{CB}$ showed higher $\mathrm{W}$ values due to the large elemental losses, mainly mobile cations (Table 2) and were then located close to the $\mathrm{F}$ axis due to the retention of $\mathrm{Si}, \mathrm{Al}$, and $\mathrm{Fe}$ in clay minerals. During the early weathering stages of mafic rocks, an overall net loss of mobile elements ( $\mathrm{Mg}, \mathrm{Ca}, \mathrm{Na}$, and $\mathrm{K}$ ) follows the mineralogical transformation process, while $\mathrm{Al}, \mathrm{Fe}$, and $\mathrm{Si}$ are predominantly retained (BABECHUCK; WIDDOWSON; KAMBER, 2014 ). The location of horizons A, Bt, and BC indicates the highest weathering degree (among the samples analyzed in this work) with the highest losses of all elements (Figure 2e, Table 2). Weathering is also greater in horizon A in relation to the others. The $\mathrm{R}$ layer was located close to the $\mathrm{M}$ axis due to its lower weathering degree.

In P2, the W index behaved similarly to the CIA, CIW, and PIA indexes, pointing to horizon $\mathrm{A}$ as the most weathered (Figures 2e and 3b). In addition, there is geochemical and mineralogical variation between horizons, as all samples were plotted close to each other (Table 2, Figure 3a).

The DE captured the variation between the soil horizons of both profiles better than the CIA, CIW, and PIA indexes, mainly in P1 (Figures 2d, 2b, 3d, and 3b). In P1, the lowest $\mathrm{DE}$ was observed in horizon $\mathrm{Bt}$ due to the higher losses of Si, Al, and Fe (Figure 2d, Table 2). The low value is related to similar losses of these elements between horizons $\mathrm{A}$ and $\mathrm{Bt}$ (Table 2). These losses occur because silicate minerals are less resistant to weathering, such as pyroxene and plagioclase (Figure 2a). The highest DE values for P1 occurred in the R layer, as it is the least weathered and in horizon $\mathrm{CB}$ (Figure 2d). The DE of horizon $\mathrm{CB}$ can be explained by the retention of $\mathrm{Fe}, \mathrm{Al}$, and $\mathrm{Si}$ in the horizon, indicated by the positive balance of these elements (mainly $\mathrm{Fe}$ and $\mathrm{Al}$ ) (Table 2), pointing to greater mineralogical modification and their permanence in secondary minerals.

In $\mathrm{P} 2$, the DE reduced towards the soil surface (Figure 3d). Horizon $\mathrm{Cr}$ showed higher $\mathrm{DE}$ than horizon A because horizon $\mathrm{Cr}$ presented lower losses of all oxides than the upper horizon (Table 2). Horizon A suffers more from external weathering agents and therefore its geochemical balance is more negative for all analyzed oxides. It also loses finer particles by erosion due to the profile position in the landscape.

\section{CONCLUSION}

1. The CIA, CIW, and PIA indexes varied slightly along the profiles. Horizon A presented greater weathering. 
The weathering degree of the source material for two profiles were possible to assess;

2. The $\mathrm{W}$ index was more suitable to evaluate the weathering degree of recent developed soils of igneous material than the CIA, CIW, and PIA indexes. They showed greater weathering variation between horizons, especially in the more developed profile $\mathrm{P} 1$;

3. The geochemical balance was essential to explain the variations observed in the $\mathrm{W}$ and $\mathrm{DE}$ weathering indexes along the profiles;

4. The difference of elements method is proposed for element data of portable X-ray fluorescence. However, it was adequate for the analysis of the weathering degree with chemical digestion data presenting greater variation and horizon differentiation than the CIA, CIW, and PIA indexes, especially in P1. The combination of the present methodology with the geochemical balance provided information for the weathering analysis and was more adequate than the isolated observation of indexes based on the dissolution of feldspars;

5. The $\mathrm{Ki}$ and $\mathrm{Kr}$ indexes, mineralogy, and the Feo/Fed ratio helped interpret the geochemical balance and the difference of elements, important variables for studies on soil weathering.

\section{ACKNOWLEDGMENTS}

To the Coordination for the Improvement of Higher Education Personnel (CAPES- cod. financ. 001), to the National Council for Scientific and Technological Development (CNPQ), and to FAPESP (Thematic Project: Getechnologies in Detailed Digital Pedological Mapping and Spectral Soil Library in Brazil Process 2014/22262-0) for funding research grants. The authors also thank the Geotechnology in Soil Science group, GEOCIS, for the technical support (https://esalqgeocis.wixsite.com/geocis).

\section{REFERENCES}

ALVARES, C. A. et al. Köppen's climate classification map for Brazil. Meteorologische Zeitschrift, v. 22, p. 711-728, 2013.

BABECHUCK, M. G.; WIDDOWSON, M.; KAMBER, B. S. Quantifying chemical weathering intensity and trace element realese from two contrasting basalt profiles, Deccan Traps, India. Chemical Geology, v. 363, p. 56-75, 2014.

BERNER, E. K.; BERNER, R. A. Global environment: water, air and geochemical cycles. 2. ed. New Jersey: Prentice Hal, 2012. 367 p.
BIDDLE, D. L.; CHITTLEBOROUGH, D. J.; FITZPATRICK, R. W. An algorithm to model mass balances quantitatively. Computer and Geociences, v. 24, p. 77-82, 1998.

BROWN, G.; BRINDLEY, G. W. X-ray diffraction procedures for clay mineral identification. In: BRINDLEY, G. W; BROWN, G. Crystal structures of clay minerals and their Xray identification. London: Mineralogical Society, 1980. chapter 5, p. 305-360.

BUOL, S. W. et al. Soil genesis and classification. 6. ed. [S. l.]: Wiley-Blackwell, 2011.

CARVALHO FILHO, A. et al. Óxidos de manganês em solos do quadrilátero ferrífero (MG). Revista Brasileira de Ciência do Solo, v. 35, p. 793-804, 2011.

FEDO, C. M.; NESBITT, H. W.; YOUNG, G. M. Unravelling the effects of potassium metasomatism in sedimentary rocks and paleosols, with implications for paleoweathering conditions and provenance. Geology, v. 23, p. 921-924, 1995

FERREIRA, E. P.; GUERRA, A. R.; DE AZEVEDO, A. C. Rare earth elements in gneiss regoliths in southern Minas Gerais, Brazil. Scientia Agricola, v. 78, n. 3, 2021.

GARZANTI, E.; RESENTINI, A. Provenance control on chemical indices of weathering (Taiwan river sands). Sedimentary Geology, v. 336, p. 81-95, 2016.

GILL, R. Igneous rocks and process: a practical guide. [S. l.]: Wiley-Blackwell, 2010.

GUIMARÃES, C. C. B. et al. Interpreting regolith data to infer groundwater potential contamination in Piracicaba, Brazil. Journal of South American Earth Sciences, v. 109, p. 103298, 2021.

HARNOIS, L. The CIW index: a new chemical index of weathering. Sediment Geology, v. 55, p. 319-322, 1988.

IUSS WORKING GROUP WRB. World Reference Base for Soil Resources 2014, update 2015 International soil classification system for naming soils and creating legends for soil maps., 106 th ed, Experimental Agriculture. FAO, Rome. 2015.

LE BLOND, J. S. et al. Weathering of the Ethiopian volcanic province: a new weathering index to characterize and compare soils. American Mineralogist, v. 100, p. 2518-2535, 2015.

MEHRA, O. P.; JACKSON, M. L. Iron oxide removal from soils and clays by a dithionite-citrate system buffered with sodium bicarbonate. Clays and Clay Minerals, p. 317-327, 1960.

MELFI, A. J.; LEVI, F. Geochemical and mineralogical study in the first stages of weathering of basic and related rocks. Revista Brasileira de Geociências, v. 1, p. 22-28, 1971.

NESBITT, H. W.; YOUNG, G. M. Formation and diagenesis of weathering profiles. The Journal of Geology, v. 92, p. 129-147, 1989.

NOVAES FILHO, J. P. et al. Indicativos de descontinuidade litológica de regolitos derivados de granitos em uma microbacia sob floresta amazônica, em Jurena, MT. Revista Brasileira de Ciência do Solo, v. 3, p. 317-324, 2012. 
OHTA, T.; ARAI, H. Statistical empirical index of chemical weathering in igneous rocks: a new tool for evaluating the degree of weathering. Chemical Geology, v. 240, p. 280-297, 2007.

ORIOLO, S. et al. Basalt weathering as the key to understand the past human use of hematite- based pigments in southernmost Patagonia. Journal of South America Earth Sciences, v. 96, p. 102376, 2019.

PINHEIRO, M. R.; QUEIROZ NETO, J. P. Reflexões sobre a gênese da Serra Geral e da Depressão Periférica Paulista: o exemplo da região da Serra de São Pedro e do Baixo Piracicaba, SP. Revista do Instituto Geológico, v. 35, p. 47-59, 2014.

PUTZ, H. MATCH! Phase identification from powder diffraction. Germany: Crystal Impact, 2016. 119p.

RUDORFF, B. F. T. et al. Studies on the rapid expansion of sugarcane for ethanol production in São Paulo State (Brazil) using Landsat data. Remote sensing, v. 2, n. 4, p. 1057-1076, 2010.

BERNER, E. K.; BERNER, R. A. Global environment: water, air and geochemical cycles. 2. ed. New Jersey: Prentice Hal, 2012.367p.

BIDDLE, D. L.; CHITTLEBOROUGH, D. J.; FITZPATRICK, R. W. An algorithm to model mass balances quantitatively. Computer and Geociences, v. 24, p. 77-82, 1998.

BROWN, G.; BRINDLEY, G. W. X-ray diffraction procedures for clay mineral identification. In: BRINDLEY, G. W; BROWN, G. Crystal structures of clay minerals and their Xray identification. London: Mineralogical Society, 1980. chapter 5, p. 305-360.

BUOL, S. W. et al. Soil genesis and classification. 6. ed. [S. l.]: Wiley-Blackwell, 2011.

CARVALHO FILHO, A. et al. Óxidos de manganês em solos do quadrilátero ferrífero (MG). Revista Brasileira de Ciência do Solo, v. 35, p. 793-804, 2011.

FEDO, C. M.; NESBITT, H. W.; YOUNG, G. M. Unravelling the effects of potassium metasomatism in sedimentary rocks and paleosols, with implications for paleoweathering conditions and provenance. Geology, v. 23, p. 921-924, 1995.

FERREIRA, E. P.; GUERRA, A. R.; DE AZEVEDO, A. C. Rare earth elements in gneiss regoliths in southern Minas Gerais, Brazil. Scientia Agricola, v. 78, n. 3, 2021.

GARZANTI, E.; RESENTINI, A. Provenance control on chemical indices of weathering (Taiwan river sands). Sedimentary Geology, v. 336, p. 81-95, 2016.

GILL, R. Igneous rocks and process: a practical guide. [S. l.]: Wiley-Blackwell, 2010.

GUIMARÃES, C. C. B. et al. Interpreting regolith data to infer groundwater potential contamination in Piracicaba, Brazil. Journal of South American Earth Sciences, v. 109, p. 103298, 2021.

HARNOIS, L. The CIW index: a new chemical index of weathering. Sediment Geology, v. 55, p. 319-322, 1988.

JACKSON, M. L. Soil chemical analysis: advanced course. 2nd ed. Madison, USA: University of Wisconsin, 1969.

LE BLOND, J. S. et al. Production of potentially hazardous respirable silica airborne particulate from the burning of sugarcane. Atmospheric Environment, v. 42, p. 5558-5568, 2008.
LE BLOND, J. S. et al. Weathering of the Ethiopian volcanic province: a new weathering index to characterize and compare soils. American Mineralogist, v. 100, p. 2518-2535, 2015.

MEHRA, O. P.; JACKSON, M. L. Iron oxide removal from soils and clays by a dithionite-citrate system buffered with sodium bicarbonate. Clays and Clay Minerals, p. 317-327, 1960.

MELFI, A. J.; LEVI, F. Geochemical and mineralogical study in the first stages of weathering of basic and related rocks. Revista Brasileira de Geociências, v. 1, p. 22-28, 1971.

NESBITT, H. W.; YOUNG, G. M. Formation and diagenesis of weathering profiles. The Journal of Geology, v. 92, p. 129-147, 1989.

NOVAES FILHO, J. P. et al. Indicativos de descontinuidade litológica de regolitos derivados de granitos em uma microbacia sob floresta amazônica, em Jurena, MT. Revista Brasileira de Ciência do Solo, v. 3, p. 317-324, 2012.

OHTA, T.; ARAI, H. Statistical empirical index of chemical weathering in igneous rocks: a new tool for evaluating the degree of weathering. Chemical Geology, v. 240, p. 280-297, 2007.

ORIOLO, S. et al. Basalt weathering as the key to understand the past human use of hematite- based pigments in southernmost Patagonia. Journal of South America Earth Sciences, v. 96, p. 102376, 2019.

PINHEIRO, M. R.; QUEIROZ NETO, J. P. Reflexões sobre a gênese da Serra Geral e da Depressão Periférica Paulista: o exemplo da região da Serra de São Pedro e do Baixo Piracicaba, SP. Revista do Instituto Geológico, v. 35, p. 47-59, 2014.

PUTZ, H. MATCH! Phase identification from powder diffraction. Germany: Crystal Impact, 2016. 119p.

RUDORFF, B. F. T. et al. Studies on the rapid expansion of sugarcane for ethanol production in São Paulo State (Brazil) using Landsat data. Remote sensing, v. 2, n. 4, p. 1057-1076, 2010.

SANTOS, H. G. et al. Sistema brasileiro de classificação de solos. 5. ed. Brasília: Embrapa, 2018.

SANTOS, R. D. et al. Manual de descrição e coleta de solos no campo. 7. ed. Viçosa, MG: Sociedade Brasileira de Ciência do Solo, 2015.

SCHWERTMANN, U. Differenzierung der Eisenoxide des Bodens durch Extraktion mit Ammoniumoxalat-Lösung. Zeitschrift für Pflanzenernährung, Düngung, Bodenkunde, v. 105, p. 194-202, 1964.

SZILAS, K.; GARDE, A. A. Mesoarchaean aluminous rocks at Storø, southern West Greenland: new age data and evidence of premetamorphic seafloor weathering of basalts. Chemical Geology, v. 354, p. 124-138, 2013.

TEIXEIRA, P. C. et al. Manual de métodos de análise de solo. 3. ed. Brasília: Embrapa Solos, 2017.

WEINDORF, D. C. et al. Enhanced pedon horizonation using portable X-ray fluorescence spectrometry. Soil Science Society of America Journal, v. 76, p. 522-531, 2012.

ZHENG, G. et al. Analysis of soil chronosequence studies using reflectance spectroscopy. International Journal of Remote Sensing, v. 37, p. 1881-1901, 2016. 